\title{
The Effects of Covid-19 on the Financial Sector and the Role of Social Media as an Advertising Tool in these Trying Times in Zimbabwe
}

\author{
Enesiti Chirume \\ Faculty of Humanities and Social Sciences, Catholic University of Zimbabwe, Hartfield, Zimbabwe \\ info@cuz.ac.zw, chirume163@yahoo.com
}

\begin{abstract}
This study identifies the effects of COVID-19 on the financial sector, and explores the part played by social media as an advertising instrument in Zimbabwe. The objectives of the study are - (i) to identify the effects of COVID-19 on the financial sector in Zimbabwe. ii) To appraise the function of social media as advertising vehicle in these trying times, in Zimbabwe. Drawing respondents from ten (10) leading financial institutions in Zimbabwe, the study uses a self-administered interview schedule and adopts the qualitative research design. Challenges identified range from managing the legal tender and interchangeability to methodizing working routine (dropping profits and staff well-being). There are also pressures on financial institutions notably, the rise of fintech within the sector to serve customer needs. Even though the pandemic has a terrible negative impact, thanks to social media for becoming primary sources of information. This paper agrees with some scholarly views on what ought to be the additional and new role of social media as an advertising tool- and that is relating social media benefactions to the concurrent milieu. For financial institutions, it is not business as usual. The substance of the matter is that duration of the plight and its impact are still undetermined in Zimbabwe and elsewhere. This phase presents a singular chance for the financial institutions in Zimbabwe to use social media advertising to its best, to tether with clients in significant ways. This includes adjusting advertising campaigns, evaluating the language used in advertisements and becoming aware of consumers' increased anxiety during these trying times. The study recommends that financial institutions have to think through creative advertising strategies and practices that may navigate the business through this "new normal." They should use social media more for communal rather than for commercial purposes now and after.
\end{abstract}

Keywords: Homebound, liquidity, media consumption, "new normal", pressures.

\section{Introduction and Background}

The coronavirus disease 2019 (COVID-19) upsurge has dispensed outright suffering to livelihoods across the nation. The financial sector in Zimbabwe equally finds itself relentlessly afflicted by this crisis. This paper has a twofold purpose: - to identify the effects of COVID-19 on the financial sector and to appraise the function of social media as an advertising instrument in Zimbabwe. In an attempt to understand the repercussions of the rampant scourge on the financial sector in Zimbabwe, and the role of social media as an advertising tool, it is illuminating to note that although COVID-19 has other distresses; it nonetheless has far-reaching economic aftermaths on the financial sector. The study takes interest in the aforementioned issues, primarily because financial services are fundamental to prosperity (Bonga, 2010). Given that, the banking industry is the heart of the economic development of a country, the researcher finds a compelling reason to undertake such a study. The fiscal system in many of the developing countries (such as Zimbabwe) faces various pervasive problems (Portes, (2020). These problems took a toll with the advent of the COVID-19 pandemic.

In both normal and harsh times, banks play crucial roles (Portes, 2020). They create money in the economy by making loans to different economic sectors. Thus, banks are in the epicenter of capital formation. Banks receive money and pass it on to productive and needy sectors. They provide short, medium and long-term finance to priority sectors. They mobilize people and economic agents who are reluctant to deposit their money to deposit through offering deposit rates (RBZ Monetary Policy, 2017). Banks also have a function of accepting deposits, ensuring the safe return with the agreed additives, after utilizing those deposits for its lending activities (Saha, 2010). For the underprivileged, such services humble the have-nots and assist them to handle the benefits at hand to deal with impoverishment. The above scenario invites some understanding of the role of social media as an advertising tool during the COVID-19 pandemic. The researcher's interest in the role of social media as an advertising tool comes from the fact that today, social media such as Twitter, Facebook, Instagram, and so on have become the predominant threshold of information. 
Given that social media may also carry distorted information, the growing question therefore in this era revolves around the use of social media reliably. Safko (2010) argues that access to reliable information is one of the enablers that will see companies survive. In the prevailing scenario, where people are homebound with little or nothing to do, COVID-19 has led to a spike in online media consumption. Subsequently, this spike provides a very fertile ground to explore the role of social media as an advertising tool. It is against this background that the overall aim of this paper is to ascertain the effects of COVID-19 on the financial sector and the role of social media as an advertising tool in these trying times in Zimbabwe. The first objective of the study is to identify the effects of COVID-19 on the financial sector in Zimbabwe. The second is to appraise the part played by social media as an advertising instrument in these trying times in Zimbabwe. The last objective is to propose some policy recommendations that may affect the financial sector and social media advertising.

\section{Literature Review}

The unpredictability of the COVID-19 pandemic lands financial institutions in hardships such as speculations. (Drechsel and Kalemli-Ozcan, 2020). Perceivably, due to COVID-19, the spike in bankruptcy in Africa threatens the firmness of the financial institutions (World Economic Forum, 2020). Risk-management teams in the financial institutions are doing everything possible to move with waves of credit risk among other challenges (Hansen, Shneiderman, and Smith, 2010). It might make sense, that to survive this crisis; businesses need to maintain their customer bases. This section reviews the literature on the effects of COVID19 on the financial sector in Zimbabwe and the part played by social media as an advertising instrument in these trying times. Table 1 below shows the leading financial institutions in Zimbabwe.

Table 1: Operating Financial Institutions in Zimbabwe

\begin{tabular}{ll}
\hline Name & No. of Branches \\
\hline First Capital Bank Limited (formerly Barclays Bank of Zimbabwe & $\mathbf{2 6}$ \\
The Small and Medium Enterprises Development Corporation & $\mathbf{6}$ \\
Agricultural Development Bank of Zimbabwe (Agri bank) & $\mathbf{4 7}$ \\
Infrastructure Development Bank of Zimbabwe (IDBZ) & $\mathbf{1 7}$ \\
Standard Chartered Bank Limited & $\mathbf{2 1}$ \\
Tetrad Investment Bank Limited & $\mathbf{5}$ \\
People's Own Savings Bank & $\mathbf{3 5}$ \\
Eco bank Zimbabwe Limited & $\mathbf{1 2}$ \\
Nedbank Zimbabwe Limited & $\mathbf{1 1}$ \\
National Building Society & $\mathbf{2}$ \\
Banc ABC Bank Limited & $\mathbf{2 7}$ \\
Steward Bank Limited & $\mathbf{2}$ \\
FBC Building Society & $\mathbf{1 7}$ \\
Stanbic Bank Limited & $\mathbf{6 7}$ \\
NMB Bank Limited & $\mathbf{2 0}$ \\
CBZ Bank Limited & $\mathbf{6 6}$ \\
FBC Bank Limited & $\mathbf{1 6}$ \\
Met bank Limited & $\mathbf{8}$ \\
ZB Bank Limited & $\mathbf{4 7}$ \\
CABS & $\mathbf{5 4}$ \\
\hline
\end{tabular}

Effects of Covid-19 on the Financial Sector of Zimbabwe: As the ramifications of the COVID-19 pandemic continue ringing with many echoes, financial institutions remain responsible for balancing their integral function (Segal and Gerstel, 2020). People will continue to need essential banking services throughout these trying times. Sad to note is the fact that in the wake of this novel coronavirus pandemic, financial institutions are facing a completely new experience. Wu and Olson (2020), observe that the pandemic is already radically worsening the economic outlook for Africa, with growth expected to collapse to a negative $1.6 \%$ and a real per capita fall of 3.9\%, making the year 2020 the worst. The available literature in Zimbabwe shows that the COVID-19 pandemic could be the most serious challenge to financial institutions in nearly a long time back. According to Segal and Gerstel, (2020) the performance of financial institutions suffer in the areas of fees, interest revenue, losses, and expenses. 
These institutions have to engage in the widespread use of remote services. The forced remote work increases costs for setups. This sudden change to operating from homes has necessitated the need to channel funds towards network set-ups to meet client's needs. Furthermore, institution portfolios are under stress because of lending to households with volatile income and no assets, some of whom may be unable to maintain solvency (Whitaker, 2020). The sector faces yet another mammoth task of ensuring effective crisis responses, managing supply-chain disruptions, and safeguarding the well-being of its employees by adjusting daily working practices (Mattei and Gombeski, 2020). Close to that, banks may not be able to retain their full workforce given the worsening market conditions and increasing cost pressures. In addition, financial institutions have to deal with the varied needs of their employees and customers from an experience, innovation, and delight perspective in order to provide various financial services, while preserving the trust and security of the customers (English and Liang, 2020). This terrible phrase in the history of financial institutions requires them to perceive social media use as an important advertising tool to retain clients.

Social Media during these Trying Times: Social media as an umbrella term needs defining to start with, to understand what it is as well as its role as an advertising tool. Given the variety of terms used to describe social media, it is not surprising that it also lacks a formal and well-accepted definition (Xiang and Gretzel, 2010). In this writing, the researcher conceives social media as a $21^{\text {st }}$ Century catch-all term that characterizes everything that has to do with the internet and the interaction of robotics (Billows, Baghel and Kavoura, 2014). In the same vein, Hudson (2018), purports that, social media refers to websites and applications that are designed to allow people to share content quickly, efficiently, and in real-time. The definition of social media is conceivably changing daily and will continue to do so. For markers, perhaps, the question might be; if social media represents a growing medium that could rapidly bring about more awareness, raise funds, and even promote positive social action, how can they use it to create positive change in Zimbabwe, in the face of COVID-19? Social media has been in existence since the early 2000s. It is an ever-changing array of tools and platforms built for any number of purposes as shown by the infographic in Figure 1 below.

Figure: 1 Social Media 2004 to 2015

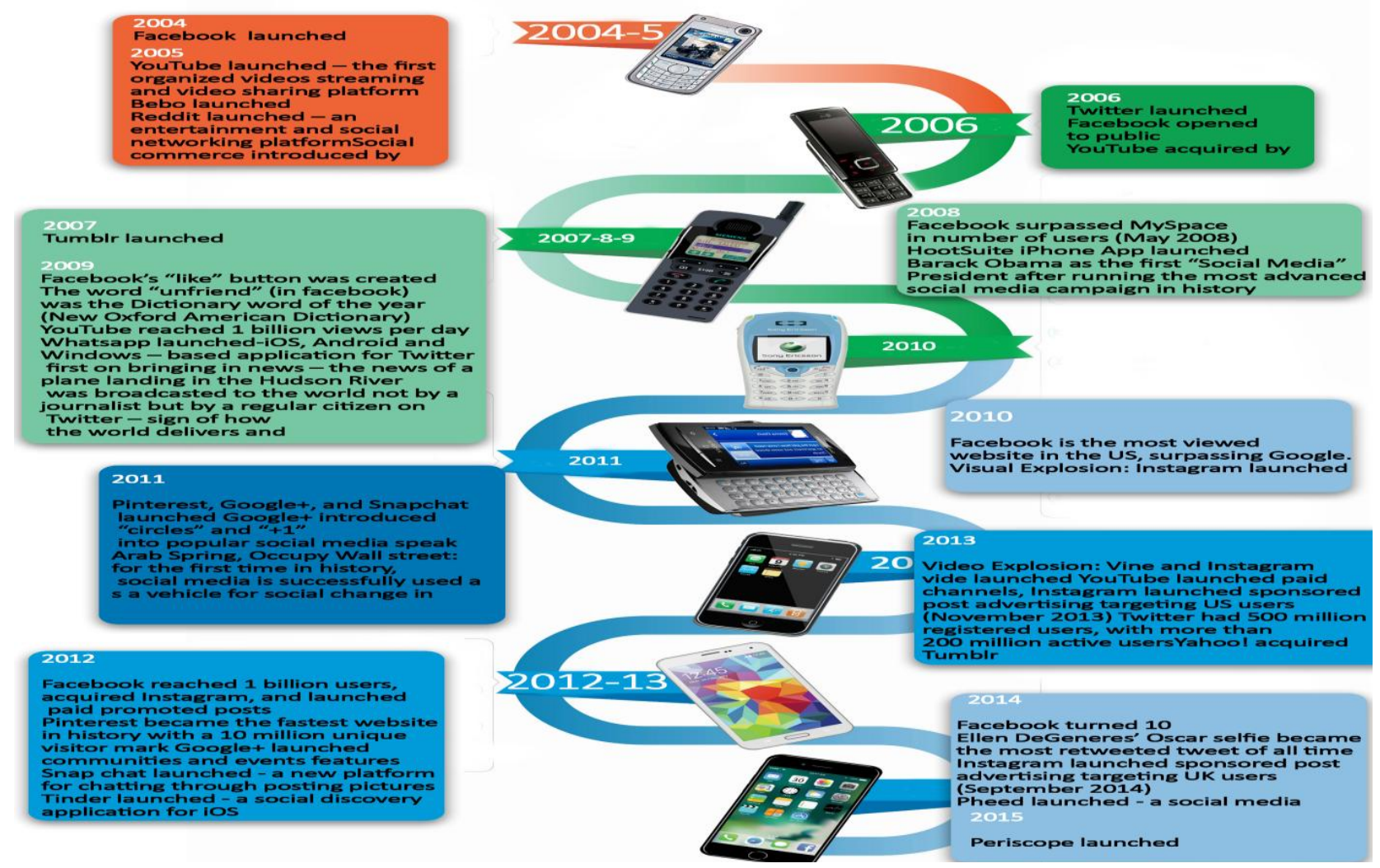

Source: -Internet Marketing Agent, (2015). 
As echoed by many scholars, social media is inexpensive since it uses the internet. Put simply, social media is all about facilitating people to express and share ideas, thoughts, and opinions with others. It is also about enabling people to connect with a lot of others. It has removed the burden of time constraints that were inherent in the traditional methods of communications. In the words of Acar and Polonsky (2007), "social media has provided online tools that enable one to many sharing of multimedia content and employs easy to use interfaces that enable even non-specialists to share and connect". From the professional front, it has been widely used for acquiring markets by new business ventures. Kaplan and Haenlein (2010), describe social media in relation to advertising as a system, which allows users to engage, collaborate, interact and share ideas. In fact, what it will be tomorrow; is virtually unpredictable for most of us. In this day, marketers should see social media with fresh eyes, as a powerful tool of marketing their businesses as well as addressing customer needs and strengthen relationships. The challenge for marketers, then, is to find new ways to capture the attention of consumers bombarded with too much digital noise or information every second of the day. Social media analysis ceases to be an added option, rather a necessity when businesses want their clients to take social media marketing to a completely new level. Close to this idea, one other area of focus in this paper, is streamlining the role of social media as an advertising tool during these trying times in Zimbabwe. Blundell and Machin (2020) propose that the first rule of advertising is that an advert has to have an effect.

At a time of crisis such as the COVID-19, people must dispense perceptions and experiences, assisting one another to attenuate the knock of COVID-19 on the financial institution and the all-embracing economy. In comparison to print and other media platforms, social media has become the major vehicle for information dissemination (Brown and Rocha, 2020). Many people are using Twitter, Facebook, and Instagram to stay current. Interestingly, in these trying times di Mauro, and Syverson (2020), have this to say, "...this crisis highlights the particular strengths of social media in how it can be used for the second type of purpose - that is a community and emotional support." The researcher finds the foregoing opinion plausible, particularly, given that financial intuitions could capitalize the duration of covid-19 to engage social media advertising in getting in touch with clients (Erken, 2020). When clients view a company's brand as solicitous rather than as a source of income, they tend to pay attention to what the company suggests. Contemporary scholars, such as Deb et al. (2020), perceive this as the distinction between using social media to talk to customers versus using social media to talk with customers and have them talk to each other through the company's brand. In this environment, therefore, understanding what customers feel, think, and say about a company in real-time is ever more critical. With the advent of COVID-19, financial institutions' customary and habitual practice transposed swiftly to working online. Social media helps financial institutions to be visible. Elgin, Basbug and Yalaman (2020), are of the view that devoted and trustworthy clients would maintain a company's operations booming, any time after the trying times, all because of social media. In the same view, they believe that, at the end of the scourge, companies will benefit from customers.

Social media has afforded clients and service providers to remain in touch despite quarantines. In the view of Sedlácek, and Sterk (2020), financial institutions could grasp the unequivocal power of social media to disseminate cooperative information and buttress employees and clients wholesomely. Due to the COVID-19 pandemic in Zimbabwe, the financial institutions have collaborated with a trusted civil society organization to randomize the timing of the dissemination of messages aimed at targeting misinformation about the virus to 27,000 newsletter WhatsApp subscribers (Saha, 2010). It examines how exposure to these messages affects individuals' beliefs about how to deal with the virus and preventative behavior. In a survey of 864 survey respondents, it found a $0.26 \sigma$ increase in knowledge about COVID-19 as measured by responses to factual questions. Through a list experiment embedded in the survey, it further found out that potentially harmful behavior - not abiding by lockdown guidelines decreased by 30 percentage points. Dabla-Norris and Khalid (2020), suggest that, since the pandemic experience of this magnitude is the unique world over, social media's role is bound to keep growing. In understanding the nature of the pandemic after it has gone, upcoming cooperates will master workable ploys to handle such an unparalleled worldwide scourge. Social media has facilitated a unique alternative popularly dubbed "Get in front of the camera" to break the physical contact barriers. Going live on social media is a great way to continue making a human connection with the audience, especially when they are craving it the most during these times of social distancing. It is also the researcher's view that when properly used, social media can be a powerful tool in these trying times of the COVID-19 pandemic and beyond. 
Policy Proposals: All eyes turn to the financial services industry to see if they can respond in a manner that reduces the economic impact of COVID-19. Nevertheless, the ever-looming rocketing social media usage is likely to stay there after the removal of lockdown restrictions. Social media will prevail as a pointer in fixing the identity, and direction of how businesses win clients forging ahead. If that becomes the order of the day, it may, therefore, be prudent for the financial institutions to particularly give careful attention to strategy and brand issues that will define their future, as market forces and customer behaviors potentially change coming out of this crisis. This study, therefore, recommends serious consideration of this upcoming second function of social media -which is, community and emotional support, and not just marketing their businesses.

\section{Methodology}

The study used a qualitative research technique coupled with a descriptive analysis because the underlying relationships of the research variables such as; the effects of covid-19 on the financial institutions and the role, of social media as an advertising tool were articulated (Craven, Liu, Mysore and Wilson, 2020). If the goal is to chronicle a phenomenon, such as in this current paper, the right choice is to use qualitative methods. Qualitative studies facilitate in-depth and detailed study of phenomena. According to Morse (1999), qualitative methods not only provide us with the means to explore complex and chaotic real-life situations, such as the current one, but also provide us with diverse options about how to deal with settings in line with the research problem.

Identification of the Population: From the twenty (20) leading financial institutions, (see Table 1), the researcher used a sample size of ten (10) financial institutions with the aid of a stratified random sampling technique to identify the financial institutions for prospective respondents.

Research Instruments: A semi-structured interview design was used as the major research strategy to gather data; the tool was segmented into three sections focusing on demographic and business profile information, questions on knowledge about effects of COVID-19 on financial institutions and finally questions on the role of social media as an advertising tool in Zimbabwe. The interviews targeted marketing managers of the selected financial institutions in Chinhoyi.

Data Analysis: Interview questions captured data on two fronts. The section after the social and demographic questions dealt with the effects of COVID-19 on financial institutions in general. The other section carried questions on the part played by social media as an advertising device in Zimbabwe. The researcher managed to interview all the intended ten (10) marketing managers. The data analysis from the sample generally, shows that the COVID-19 crisis has compelled companies to alter operations. The major effects of the virus on financial institutions as shown by the participants ranged from maintaining cash and liquidity to re-adjusting operations. Respondents overwhelmingly, agreed that the rocketing COVID-19 upsurge accounts for both a supply and a demand shock whose full immensity, duration and social aftermath are unknown. Most respondents $80 \%$ agreed that almost all financial institutions in Zimbabwe currently face the challenge of available means and profitability, which endangers an already ailing fiscal position. A big number of $85 \%$ expressed that financial institutions are under stress because of lending clients with unstable earnings.

The majority of such clients may fail to own up. Close to $80 \%$ indicated that there was a hike in uncollectible loans and about $80 \%$ again indicated that the acute swings in investor sentiment due to the COVID-19 virus have affected lending to the private sector. On the question of the almost overnight switch to remote working, $65 \%$ of the respondents felt that it has heightened the need for financing computerized information tools. In addition, a majority of $75 \%$ of the respondents indicated that because of changes in operations, there is increased fraud and information security risk. On a lighter note, $75 \%$ of the respondents felt that, even though COVID-19 may have the potential to destabilize the economy, the general thrust to move forward to digitization is leveraged. A clear understanding by banking operators of their gap in the provision of services is becoming more tangible than ever before, with COVID-19, making them even more inclined to accelerate the digital transformation path through partnerships and collaborations within the fintech community in Zimbabwe. About $75 \%$ of the respondents agreed that financial institutions have shown a realization of the seemingly two contesting syllogisms. 
On one hand, companies can use social media for commercial advantage. On the other, for mutual neighborhood. In other words, companies use social media to mark, trade, merchandise their business. The researcher appreciates a scenario where financial institutions need not just relay information to customers in a linear method rather it should be transactional. The majority $80 \%$ of respondents agreed that social media are becoming primary sources of information and that they can now play a new role in fostering the welfare of the community - not just reaping from it. Half of the respondents held the view that even though, for most banks, cyber security is a key part of crisis management; social media warns and educates consumers on how hackers capitalize the setting to pilfer private and personalized information. In these significantly higher levels of remote access to data and core systems, therefore, employees and management do not become more susceptible to social maneuvers in light of the plight.

\section{Results and Discussions}

From the findings, the financial sector in Zimbabwe has suffered severe COVID-19 scourge at the time. The study reveals that the coronavirus outbreak has caused extensive and widespread economic woes for consumers, businesses and communities in Zimbabwe. The key highlights of the research findings are-

- The Zimbabwean economy has been ill-equipped to cope with the mounting risks of COVID-19 given its already ailing economy.

- COVID-19 imposed restrictions have stemmed foreign currency inflows into Zimbabwe.

- There is an anticipation of increased electronic printing of money, which may further undermine the measures to tackle hyperinflation and exchange rate volatility in Zimbabwe.

- The customary banking framework in Zimbabwe is disintegrating at the time, preserving capital rather than lending. The study reveals that increased provisions for credit losses and lower interest income from a sustained decrease in interest rates dominate the financial sector of Zimbabwe. Thus, a spike in bankruptcy was witnessed in these financial institutions.

Results significantly reveal that the scourge has forced financial institutions to change how they work especially in re-adjusting operations. The sector has witnessed increases in costs for setups because of the forced remote work, which arrived without any form of preparation. Institutions are in a dilemma figuring out whether to lend or not to a client who may not be able to settle their dues. The study also shows a general perception by customers seeing banks as having abandoned them in their moment of need. Because of this, customers switch banks. At the time of writing, the study reveals a burden on the fiscal state of financial institutions whose consequences are unknown. Most importantly, the study reveals that social media is proving, to be the primary sources of information and that they have another role, for mutual neighborhoods especially in these trying times. These unprecedented challenges may continue to have a broad impact on the risk profile of financial institutions in Zimbabwe for some time, both financially and operationally. For the financial sector, this takes on heightened importance during this crisis, because trust and reputation are integral to what they offer clients. Now that people resort to social media, not only for amusement but also for use as information provenance, the financial sector should seriously consider the second function recommended in this paper.

The researcher agrees with Wolter and Kranzusch (2020) when they propose that, "instead of self-glorifying social media brand posts, brands should be seen to embrace the communal logic of social media during the COVID-19 crisis." Guterres (2020) argues that the need to have social media circulations should be cozy to the user and not just comfortable to the producer. The researcher feels that brands that put customers first, with the helpful information in these trying times, will stand and excel after the crisis. Within this research paper, the researcher finds reason to add voice and say that it is time that marketers should connect their social media subscriptions to the real-time context. Hassan (2020) argues that "during the COVID-19 pandemic, companies that lead with empathy and genuinely address customer needs can strengthen relationships". As an overall aspect of the findings and the arguments in the literature review, therefore, marketers should see social media with fresh eyes, as a powerful tool of marketing their businesses as well as addressing customer needs and strengthen relationships. Lastly and interestingly to note, is that the digital economy is booming, who knows COVID-19 might be a blessing in propelling countries like Zimbabwe which have been sleeping giants for a very long time to create valuable solutions for the digital economy. 


\section{Conclusion}

It may not be debatable that during the COVID-19 pandemic, distinguishing and disseminating correct information remain a battle. Based on the findings, one thing certain perhaps is that the practices of patrons will keep transposing in against the COVID-19 pandemic. This paper concludes that, while COVID-19 presents a crunch time for businesses going forward, it is important to realize that the current media environment is a major shift no marketer has navigated before and is changing constantly. If financial institutions are looking for a North Star in today's unsettling times, then social media advertising should focus on community and emotional support as revealed in the findings. Consumers are looking for solace and fellow feeling, honest relationship, cushion and support. On the whole, the run-up to today's tense atmosphere has seen social media play all kinds of roles. At its best, it has brought timely information to people, increasingly, people who are, shut-in. Social media, done well, lends itself to combining speed with trust-building in these trying times.

\section{References}

Acar, A. S. \& Polonsky, M. (2007). Online social networks and insights into marketing communications. Journal of Internet Commerce, 6(4), 55-72.

Billows, S., Baghel, L. \& Kavoura, A. (2014). Organizations' advertising and communication activities for innovation with social media and the creation of the sense of belonging with customers in the digital era.

Blundell, J. \& Machin, S. (2020). Self-employment in the Covid-19 crisis, CEP COVID-19 analysis, No. 003, Centre for Economic.

Bonga, W. (2010). Economic Development, Derivatives Markets. Financial Gazette, Zimbabwe Economic Society Articles.

Brown, R. \& Rocha, A. (2020). Entrepreneurial Uncertainty during the Covid-19 Crisis: Mapping the Temporal Dynamics of Entrepreneurial Finance, Working Papers in Responsible Banking \& Finance, No. 20008, University of St Andrews.

Craven, M., Liu, L., Mysore, M. \& Wilson, M. (2020). COVID-19: Implications for Business. Executive Briefing, COVID-19: Briefing note, McKinsey \& Company.

Dabla-Norris \& Khalid, S. (2020). Who will bear the Brunt of Lockdown Policies? Evidence from Teleworkability Measures across Countries, IMF Working Papers, No. 20/88, IMF (accessed on 9 December 2020).

Deb, P., Furceri, D., Ostry, J. D. \& Tawk, N. (2020). The economic effects of COVID-19 containment measures, VOX, CEPR Policy Portal, https://voxeu.org/article/economic-effects-covid-19-containmentmeasures.

di Mauro, F. \& Syverson, C. (2020). The COVID crisis and productivity growth, VOX, CEPR Policy Portal.

Drechsel, T. \& Kalemli-Ozcan, S. (2020). A proposal for a negative SME tax | VOX, CEPR Policy Portal, VOX CEPR Policy Portal, https://voxeu.org/article/proposal-negative-sme-tax (accessed on 15 December 2020).

Elgin, C., Basbug, G. \& Yalaman, A. (2020). Economic policy responses to a pandemic: A COVID-19 Economic Stimulus Index, VOX, CEPR Policy Portal, https://voxeu.org/article/economic-policy-responsespandemic-covid-19-economic-stimulus-index (accessed on 24 December 2020).

English, W. \& Liang, J. (2020). Designing the Main Street Lending Program: Challenges and Options, Hutchins Center Working Paper, No.64, Brookings Institution, https://www.brookings.edu/research/designing-the- (accessed on 23 December 2020).

Erken, H. (2020). Looking beyond the COVID-19 crisis, Rabobank.

Guterres, A. (2020). Symposium on the impact of the pandemic. Measuring the Effect of COVID-19 on U.S. Small Businesses: The Small Business Pulse Survey. https://www.census.gov/library/workingpapers/2020/adrm/CES-WP-20-16.html (accessed on 24 December 2020).

Hansen, D., Shneiderman, B. \& Smith, M. A. (2010). Analyzing social media networks with NodeXL:

Hassan, T. (2020). Firm-Level Exposure to Epidemic Diseases: Covid-19, SARS, and H1N1, Institute for New Economic Thinking Working Papers, No. 119.

Hudson, S. (2018). Consumer Behavior Related to Tourism. In: Pizam, A. and Mansfeld, Y., eds. Consumer Behavior in Travel and Tourism. Binghamton, NY: Haworth Press, 7-30. 
Kaplan, A. M. \& Haenlein, M. (2010). Users of the world, unite! The challenges and opportunities of social media. Business Horizons, 53(1), 69-68.

Mattei, A. \& Gombeski, P. (2020). Is Social Media a New Banking Market? Novantas. Available on www.novantas.com (accessed on 6 December 2020).

Morse, M. J. (1999). Qualitative Methods. The State of the Art. Qualitative Health Research, 9(3), 393-406.

Portes, J. (2020). The lasting scars of the Covid-19 crisis.

Safko, L. (2010). The Social Media Bible: Tactics, Tools, and Strategies for Business Success, 2nd ed., John Wiley and Sons Inc., Hoboken, NJ.

Saha, S. K. (2010). Role of Banks in Indian Economy. Calcutta Business Retrieved from https://www.mckinsey.com/business-functions/risk/our-insights (accessed on 26 December 2020).

Sedlácek, P. \& Sterk, V. (2020). Startups and employment following the COVID-19 pandemic: A calculator, COVID Economics13 https://cepr.org/sites/default/files/news/CovidEconomics13.pdf.

Segal, S. \& Gerstel, D. (2020). Breaking Down the G20 Covid-19 Fiscal Response.

The Reserve Bank of Zimbabwe. (2017). Monetary Policy Statement. Harare.

Whitaker, V. (2020). What your customers want and how social media can help you give it to them. http://www.socialbuzzing.co.uk/what-your-customers-want-and-how-social-media-can-help-yougive-it-to-them/ (accessed on 18 December 2020).

Wolter H. \& Kranzusch, P. (2020). Preliminary assessments of the IfM Bonn on the economic impact of the coronavirus pandemic on the "Mittelstand" businesses in Germany, IfM-Background Paper, IFM, Bonn.

World Economic Forum. (2020). Four ways governments can support start-ups and save their economies, https://,.weforum.org/agenda/2020/06/4-ways-governments-can-support-start-ups-and-savetheir-economies/ (accessed on 24 December 2020).

Wu, D. D. \& Olson, D. L. (2020). The Effect of COVID-19 on the Banking Sector. In: Pandemic Risk Management in Operations and Finance.

Xiang, Z. \& Gretzel, U. (2010). Role of social media in online travel information search. Tourism Management, 31(2), 179-188. 